\title{
PRZYCZYNEK DO DYSKUSJI NAD ZASADNOŚCIĄ WŁĄCZENIA DO EUROPEJSKIEGO SYSTEMU HANDLU EMISJAMI SEKTORÓW DOTYCHCZAS NIEOBJĘTYCH SYSTEMEM
}

\section{WSTĘP}

Do 2020 r. Unia Europejska zobowiązała się do zredukowania emisji gazów cieplarnianych o $20 \% \mathrm{w}$ stosunku do poziomu emisji w $1990 \mathrm{r}$. (14\% w stosunku do 2005 r.). Jednym z narzędzi redukcji emisji gazów cieplarnianych w Unii Europejskiej jest Europejski System Handlu Emisjami (European Union Emissions Trading System - EU ETS). Swoim zasięgiem obejmuje on jedynie wybrane sektory gospodarki, co nie oznacza, że tzw. sektory non-ETS (obszary działalności nieobjęte systemem handlu emisjami, do których odnosi się tzw. decyzja non-ETS ${ }^{1}$ ) nie mają współuczestniczyć w osiaganiu celu redukcji emisji. By osiagnaćc cel na poziomie $20 \%$ w horyzoncie do 2020 r., sektory EU ETS mają zredukować emisje o $21 \%$ w stosunku do 2005 r., a sektory nieobjęte systemem - o 10\% w porównaniu z 2005 r. w skali całej Unii Europejskiej, przy czym indywidualne cele państw członkowskich zakładają możliwość zwiększenia emisji w państwach mniej zamożnych, kosztem głębszych redukcji emisji w najzamożniejszych państwach (nawet o 20\%)². O ile jednak działanie systemu EU ETS i sposób dojścia do wyznaczonego celu redukcyjnego sa szczegółowo uregulowane na poziomie UE, o tyle wybór narzędzi osiagnięcia celu emisyjnego dla sektorów non-ETS pozostawiono w gestii państw członkowskich.

Unijna polityka redukcji emisji ma być kontynuowana po $2020 \mathrm{r}$. W horyzoncie do 2030 r. Rada Europejska przyjęła wiążący cel redukcji emisji o 40\%

${ }^{1}$ Decyzja Parlamentu Europejskiego i Rady nr 2009/406/WE z 23 kwietnia 2009 r. w sprawie wysiłków podjętych przez państwa członkowskie, zmierzających do zmniejszenia emisji gazów cieplarnianych w celu realizacji do roku 2020 zobowiązań Wspólnoty dotyczących redukcji emisji gazów cieplarnianych, Dz. Urz. UE L 140 z 5 czerwca 2009 r., s. 136-148.

${ }^{2}$ Dyrektywa Parlamentu Europejskiego i Rady 2009/29/WE z 23 kwietnia 2009 r. zmieniająca dyrektywę 2003/87/WE w celu usprawnienia i rozszerzenia wspólnotowego systemu handlu uprawnieniami do emisji gazów cieplarnianych, Dz. Urz. UE L 140 z 5 czerwca 2009 r., s. 63 87. Decyzja Parlamentu Europejskiego i Rady nr 2009/406/WE z 23 kwietnia 2009 r. w sprawie wysiłków podjętych przez państwa członkowskie, zmierzających do zmniejszenia emisji gazów cieplarnianych w celu realizacji do roku 2020 zobowiązań Wspólnoty dotyczących redukcji emisji gazów cieplarnianych, Dz. Urz. UE L 140 z 5 czerwca 2009 r., s. 136-148. 
w stosunku do poziomu w 1990 r. (EU ETS zmniejszenie emisji o 43\%, a sektory non-ETS o 30\% w stosunku do poziomów w 2005 r.) ${ }^{3}$. Do 2050 r. emisje mają zostać zredukowane o 80-95\% w stosunku do poziomu z 1990 r. ${ }^{4}$

W toku dyskusji nad możliwościami redukcji emisji gazów cieplarnianych z sektorów non-ETS pojawiła się koncepcja włączenia przynajmniej wybranych sektorów non-ETS do systemu handlu emisjami. Postulat ten uzasadniany jest korzyściami płynącymi z zastosowania właśnie tego narzędzia redukcji emisji. Nasuwa się jednak pytanie, w jaki sposób nowe sektory miałyby zostać włączone do systemu oraz czy takie działanie byłoby słuszne, tzn. doprowadziłoby do zamierzonych redukcji w sektorach non-ETS w sposób efektywny ekonomicznie. Celem niniejszego artykułu jest ocena zasadności włączenia do EU ETS - nieobjętych dotychczas systemem - emisji z transportu, rolnictwa i użytkowania budynków, z uwzględnieniem możliwych rozwiązań w tym zakresie. W opracowaniu wykorzystano metody analizy opisowej - przyczynowo-skutkowej i porównawczej. Najpierw przedstawiono korzyści wynikajace z zastosowania handlu zbywalnymi uprawnieniami do emisji jako instrumentu redukcji emisji. Następnie krótko omówiono strukturę emisji gazów cieplarnianych w Polsce i UE. Główna część opracowania została poświęcona syntetycznej analizie proponowanych w literaturze rozwiązań w zakresie włączania nowych sektorów do systemu handlu emisjami oraz ocenie zasadności włączenia transportu, rolnictwa i użytkowania budynków do EU ETS.

\section{KORZYŚCI Z WYKORZYSTANIA HANDLU EMISJAMI}

W literaturze podkreśla się rozliczne zalety systemu handlu emisjami, w szczególności systemu typu cap and trade ${ }^{5}$, jako narzędzia internalizacji ekologicznych kosztów zewnętrznych i stopniowego zmniejszania emisji.

Przede wszystkim poszczególni autorzy ${ }^{6}$ wskazują na możliwość osiagnięcia przez wykorzystanie handlu uprawnieniami do emisji założonego celu ekologicznego przy minimalnym koszcie. Efekt ten jest możliwy dzięki umożliwieniu podmiotom objętym systemem swobodnego handlu zbywalnymi uprawnieniami do emisji. Poprzez transakcje kupna-sprzedaży uprawnienia ostatecznie trafiają do tych podmiotów, które cenią je najbardziej (a więc są

${ }^{3}$ Konkluzje Rady Europejskiej EUCO 169/14 przyjęte na posiedzeniu w Brukseli 23 i 24 października 2014 r., http://www.consilium.europa.eu/uedocs/cms_data/docs/pressdata/ PL/ec/145432.pdf [dostęp: 17.04.2016].

${ }^{4}$ Komunikat Komisji do Parlamentu Europejskiego, Rady, Europejskiego Komitetu Ekonomiczno-Społecznego i Komitetu Regionów: Plan działań prowadzący do przejścia na konkurencyjną gospodarkę niskoemisyjną do 2050 r., Bruksela, 8 marca 2011 r., KOM (2011), 112 wersja ostateczna, s. 3.

${ }^{5}$ System, w którym ustala się limit emisji (ang. cap) dla całego systemu i umożliwia się podmiotom objętym systemem swobodny handel pozwoleniami na emisję. Pierwotna forma alokacji pozostaje bez znaczenia (bezpłatny przydział lub zakup na aukcjach).

${ }^{6}$ A. Graczyk, Ekologiczne koszty zewnętrzne. Identyfikacja, szacowanie, internalizacja, Wydawnictwo Ekonomia i Środowisko, Białystok 2005, s. 158-161; D. W. Pearce, R. K. Turner, Economics of Natural Resources and the Environment, The Johns Hopkins Univ. Press, Baltimore 1990, s. 111-112. 
w stanie najefektywniej je wykorzystać), a cena uprawnień kształtuje się na poziomie marginalnego kosztu redukcji jednostki zanieczyszczenia ${ }^{7}$.

Ponadto zaletą systemu jest jego wielopłaszczyznowa elastyczność. W czasie obniżonej aktywności gospodarczej (np. Europa w czasie kryzysu finansowego i zadłużeniowego) cena uprawnień spada z uwagi na niższy na nie popyt, będący wynikiem mniejszych emisji na skutek spadku produkcji ${ }^{8}$. Natomiast na poziomie pojedynczego podmiotu elastyczność przejawia się w możliwości wyboru sposobu dostosowania się: emitent może zakupić dodatkowe pozwolenia lub dokonać inwestycji zmniejszających emisje (wybór będzie podyktowany opłacalnością poszczególnych działań, która zależy m.in. od obecnej i przewidywanej ceny uprawnień do emisji). Tym samym decyzje o wprowadzeniu technologii niskoemisyjnych podejma podmioty, które są w stanie zrobić to najtaniej, co minimalizuje ogólnospołeczny koszt osiagnięcia redukcji emisji.

W przeciwieństwie do instrumentów kontroli bezpośredniej instrumenty kontroli pośredniej (w tym system handlu emisjami, ale też np. odpowiednio skonstruowane podatki emisyjne) oddziałuja na decyzje podmiotów gospodarczych przez ingerencję w ich rachunki ekonomiczne. W efekcie sprzyjają one wprowadzaniu nowych niskoemisyjnych technologii (które oznaczają mniejsze koszty). Wprowadzanie takich technologii może być niekorzystne z punktu widzenia podmiotu objętego systemem kontroli bezpośredniej, z uwagi na ryzyko zaostrzenia standardów po ujawnieniu technologii ${ }^{9}$.

Inną zaleta wykorzystania handlu emisjami do redukcji zanieczyszczeń jest możliwość jego połączenia z innymi systemami handlu emisjami. Należy tu mieć na uwadze, że globalne ocieplenie stanowi problem ogólnoświatowy i z perspektywy ograniczenia koncentracji gazów cieplarnianych nie ma znaczenia, w którym miejscu globu zostaną dokonane redukcje. W miarę przyjmowania przez kolejne kraje celów redukcyjnych i wprowadzania systemów handlu emisjami systemy te mogą być łączone na różnych zasadach, co powinno sprzyjać efektywnej kosztowo redukcji emisji gazów cieplarnianych ${ }^{10}$.

\section{STRUKTURA EMISJI GAZÓW CIEPLARNIANYCH}

Struktura emisji gazów cieplarnianych (gazy inne niż $\mathrm{CO}_{2}$ przeliczone na $\mathrm{CO}_{2}$, zgodnie $\mathrm{z}$ ich potencjałem tworzenia efektu cieplarnianego) w Unii Europejskiej i w Polsce w podziale na sektory (zgodnie ze standardami raportowania na potrzeby realizacji celów Ramowej konwencji Narodów Zjednoczonych w sprawie zmian klimatu - UNFCCC) została przedstawiona w tabeli 1.

\footnotetext{
${ }^{7}$ J. H. Dales, Land, water, and ownership, „The Canadian Journal of Economics” 1(4), 1968, s. $799-802$.

${ }^{8}$ International Emissions Trading Association, Benefits of emissions trading, http://www.ieta. org/resources/Resources/101s/ieta-emissions-trading-101-library-april2015.pdf [dostęp: 9.04.2016].

${ }^{9}$ A. Endres, C. Ohl, Kyoto, Europe? - An Economic Evaluation of the European Emission Trading Directive, „European Journal of Law and Economics” 19(1), 2005, s. 21.

${ }^{10}$ International Emissions Trading Association, op. cit.
} 


\section{Tabela 1}

Struktura emisji gazów cieplarnianych w Polsce i UE w 2013 r.

\begin{tabular}{|l|c|c|}
\hline \multicolumn{1}{|c|}{ Źródło emisji } & UE & Polska \\
\hline Spalanie paliw i emisje lotne z paliw (bez transportu) & $60 \%$ & $71 \%$ \\
\hline Transport (bez międzynarodowego lotnictwa) & $19 \%$ & $11 \%$ \\
\hline $\begin{array}{l}\text { Procesy przemysłowe oraz użytkowanie rozpuszczalników } \\
\text { i innych produktów }\end{array}$ & $8 \%$ & $8 \%$ \\
\hline Rolnictwo & $10 \%$ & $8 \%$ \\
\hline Odpady & $3 \%$ & $3 \%$ \\
\hline
\end{tabular}

Źródło: opracowanie własne na podstawie danych Eurostatu i A. Olecka et al., Poland’s National Inventory Report 2015. Greenhouse Gas Inventory for 1988-2013, KOBIZE, Warszawa 2015.

Europejski System Handlu Emisjami obejmuje instalacje stacjonarne i statki powietrzne odpowiadające za ok. $45 \%$ emisji gazów cieplarnianych w skali całej Unii Europejskiej ${ }^{11}$. Pośród emisji nieobjętych systemem pozostaja obecnie emisje z: transportu, rolnictwa i powstające w wyniku użytkowania budynków mieszkalnych i niemieszkalnych (dalej sektor ten nazywany jest użytkowaniem budynków). $\mathrm{Z}$ danych przedstawionych $\mathrm{w}$ tabeli 1 wynika, że sektory te odpowiadają za istotną część emisji gazów cieplarnianych. Użytkowanie budynków nie zostało wydzielone, ale o skali emisji z sektora świadczą dane o zużyciu energii - budynki mieszkalne i niemieszkalne odpowiadają za ok. $40 \%$ zużycia energii w UE ${ }^{12}$. Oprócz emisji bezpośrednich ze spalania paliw (w Polsce 11\% wszystkich bezpośrednich emisji gazów cieplarnianych ${ }^{13}$ ), budynki są pośrednim źródłem emisji, wynikającym ze zużycia energii elektrycznej i ciepła sieciowego. Transport, rolnictwo i budynki cechują się zróżnicowanymi możliwościami włączenia do EU ETS, co będzie przedmiotem dalszej analizy.

\section{ROZWIAZZANIA W ZAKRESIE WEĄCZENIA NOWYCH SEKTORÓW DO EU ETS I KRYTERIA OCENY}

Rozpatrując kwestie włączenia kolejnych sektorów do EU ETS, należy rozważyć, które podmioty miałby zostać objęte obowiązkami z tytułu uczestnictwa w systemie. W literaturze wyróżnia się dwa podstawowe podejścia do włączania kolejnych sektorów do systemu handlu emisjami. Zatem zasadnicza kwestia przy konstrukcji systemu jest odpowiedź na pytanie, na kogo powinien zostać nałożony obowiązek nabywania pozwoleń i rozliczania emisji: producentów dobra, które jest przyczyną emisji (podejście upstream), czy

${ }^{11}$ Komisja Europejska, Unijny System Handlu Uprawnieniami do Emisji (EU ETS), Urząd Publikacji, Unia Europejska 2013, s. 1.

12 Dyrektywa Parlamentu Europejskiego i Rady 2010/31/UE z 19 maja 2010 r. w sprawie charakterystyki energetycznej budynków, preambuła, pkt 3, Dz. Urz. UE L 153 z 18 czerwca 2010 r., s. $13-35$.

${ }^{13}$ Narodowy Program Rozwoju Gospodarki Niskoemisyjnej, projekt z 5 sierpnia 2015 r. 
jego konsumentów (podejście downstream) ${ }^{14}$. W pewnych sektorach można także wyróżnić podejście midstream, kiedy wyżej wymienionymi obowiązkami zostają obciążeni dostawcy dóbr niezbędnych do wykonywania pewnej aktywności skutkującej emisją gazów cieplarnianych (np. samochodów w przypadku emisji pochodzacej ze spalania paliw w transporcie). Możliwe są także kombinacje wymienionych podejść (ang. hybrid) ${ }^{15}$.

W odniesieniu do transportu zastosowanie podejścia downstream sprowadzałoby się do objęcia obowiązkiem monitorowania i rozliczania emisji posiadaczy/użytkowników pojazdów ${ }^{16}$. Zastosowanie podejścia midstream oznaczałoby obowiązek rozliczenia emisji przez producentów pojazdów w zależności od szacunkowych emisji pojazdu w ciagu całego okresu eksploatacji ${ }^{17}$. Ostatnim wariantem włączenia transportu do EU ETS jest nałożenie obowiązku rozliczenia emisji przez dostawców paliw, czyli zastosowanie podejścia upstream $^{18}$. Z kolei włączenie rolnictwa do EU ETS mogłoby przyjąć dwojaką formę: albo przez objęcie obowiązkiem szacowania i rozliczania emisji samych rolników (podejście downstream), albo producentów nawozów, środków ochrony roślin, pasz i innych produktów zużywanych w rolnictwie (podejście upstream). W przypadku użytkowania budynków wdrożenie podejścia downstream byłoby równoznaczne z nałożeniem obowiązków związanych z monitorowaniem i rozliczeniem emisji na właścicieli lub użytkowników budynków. Natomiast wdrożenie rozwiązania upstream we włączeniu użytkowania budynków do EU ETS oznaczałoby obowiązek rozliczania emisji przez dostawców energii do budynków mieszkalnych, komercyjnych i użyteczności publicznej (por. tab. 2).

Tabela 2

Możliwe rozwiązania w zakresie włączenia transportu, rolnictwa i użytkowania budynków do EU ETS - podmioty objęte obowiązkiem monitorowania i rozliczania emisji

\begin{tabular}{|l|l|l|l|}
\hline \multicolumn{1}{|c|}{$\begin{array}{c}\text { Podejście/ } \\
\text { sektor }\end{array}$} & \multicolumn{1}{|c|}{ Transport } & \multicolumn{1}{c|}{ Rolnictwo } & \multicolumn{1}{c|}{$\begin{array}{c}\text { Użytkowanie } \\
\text { budynków }\end{array}$} \\
\hline Upstream & Producenci paliw & $\begin{array}{l}\text { Producenci pasz, nawo- } \\
\text { zów, środków ochrony } \\
\text { roślin itp. }\end{array}$ & $\begin{array}{l}\text { Dostawcy nośników } \\
\text { energii do budynków }\end{array}$ \\
\hline Midstream & Producenci pojazdów & - & - \\
\hline Downstream & $\begin{array}{l}\text { Właściciele/użytkowni- } \\
\text { cy pojazdów }\end{array}$ & $\begin{array}{l}\text { Właściciele/użytkowni- } \\
\text { cy gospodarstw rolnych }\end{array}$ & $\begin{array}{l}\text { Właściciele/użytkowni- } \\
\text { cy budynków }\end{array}$ \\
\hline
\end{tabular}

Źródło: opracowanie własne.

${ }^{14}$ E. T. Mansur, Upstream versus Downstream Implementation of Climate Policy, http://www. dartmouth.edu/ mansur/papers/mansur_updown.pdf [dostęp: 8.04.2016].

${ }^{15}$ H. Lee, Designing Domestic Carbon Trading Systems: Key Considerations, ENRP Discussion Paper E-98-20, BCSIA Discussion Paper 98-21, Kennedy School of Government, Harvard University, October, 1998, s. ii.

${ }^{16}$ M. Achtnicht et al., Including Road Transport in the EU-ETS - An alternative for the future?, ZEW, Mannheim, 29 April 2015, http://ftp.zew.de/pub/zew-docs/gutachten/RoadTransportEU-ETS_ZEW2015.pdf [dostęp: 27.04.2016], s. 37-38.

${ }^{17}$ Ibidem, s. 39-40.

${ }^{18}$ Ibidem, s. 40-41. 
Włączenie jakiegokolwiek rodzaju działalności do systemu EU ETS musi być uzasadnione ekonomicznie, tzn. włączenie do EU ETS powinno być efektywnym, nie tylko środowiskowo, ale też kosztowo, sposobem redukcji emisji z danego rodzaju działalności. Dlatego w analizie zasadności włączenia jakiegokolwiek sektora do EU ETS nie należy zapominać o ocenie kosztów administracyjnych działania rozszerzonego systemu. Wybór podejścia w zakresie włączenia analizowanych sektorów do EU ETS miałby zasadniczy wpływ na koszty administracyjne działania rozszerzonego systemu.

Inną kwestia, która powinna zostać rozważona w kontekście wyboru narzędzia redukcji emisji, jest stymulowanie rozwoju świadomości konsumentów w zakresie następstw ich decyzji, skutkujacych emisjami gazów cieplarnianych. Wypracowanie tej świadomości jest pierwszym krokiem na drodze do podejmowania decyzji przekładajacych się na mniejsze emisje.

Kolejnym zagadnieniem wymagającym rozważenia w kontekście wyboru narzędzi ograniczenia emisji z każdego sektora w długim horyzoncie czasowym jest ustosunkowanie się do kwestii generowania przesłanek skłaniajacych do długoterminowych inwestycji w technologie zmniejszajace emisje gazów cieplarnianych. Europejski System Handlu Emisjami sam w sobie jest neutralny technologicznie i gwarantuje osiagnięcie wyznaczonego pułapu emisji (ang. cap) w sposób efektywny kosztowo (redukcje dokonywane sa przez podmioty, które są w stanie zrobić to najtaniej) ${ }^{19}$. Oznacza to m.in., że system nie promuje określonych technologii, a wszystkie sektory podlegają temu samemu mechanizmowi. Dzięki nadaniu uprawnieniom cechy zbywalności redukcje dokonywane sa w tych sektorach, gdzie jest to najtańsze (w horyzoncie podejmowania decyzji). W tym kontekście uzasadnione jest pytanie, czy - biorąc pod uwagę dalekosiężne cele redukcyjne - EU ETS w wystarczającym stopniu realizowałby funkcję stymulowania rozwoju technologii niskoemisyjnych w przypadku analizowanych sektorów. Zagadnienie to wiąże się z wielkością i specyfiką kosztów redukcji w tych sektorach.

Należy także zwrócić uwagę, że emisje w ramach EU ETS są rozliczane z dokładnością co do 1 t $\mathrm{CO}_{2}$. Zasadne jest zatem, aby emisje objęte systemem były precyzyjnie mierzalne i weryfikowalne.

W konkluzji tej części rozważań należy przyjąć, że ewaluacja zasadności włączenia emisji z transportu, rolnictwa i użytkowania budynków do EU ETS powinna zostać dokonana $\mathrm{z}$ uwzględnieniem możliwych rozwiązań w tym zakresie (podejścia: downstream, midstream i upstream) zgodnie z następujaccymi kryteriami:

- koszty transakcyjne działania rozszerzonego systemu,

- stymulowanie rozwoju świadomości właścicieli/użytkowników pojazdów, gospodarstw rolnych i budynków,

19 Report on the functioning of the European carbon market. Accompanying the document Report from the Commission to the European Parliament and the Council: Climate action progress report, including the report on the functioning of the European carbon market and the report on the review of Directive 2009/31/EC on the geological storage of carbon dioxide, Brussels, 18.11.2015, COM (2015), 576 final. 
- koszty redukcji emisji i dostateczne (z punktu widzenia dalekosiężnych celów redukcyjnych i preferowanej ścieżki dostosowania) stymulowanie inwestycji w technologie niskoemisyjne,

- precyzyjność mierzenia emisji, zapewniająca rzeczywiste ich redukcje.

\section{OCENA ZASADNOŚCI WLĄCZENIA EMISJI Z TRANSPORTU, ROLNICTWA I UŻYTKOWANIA BUDYNKÓW DO EU ETS Z UWZGLĘDNIENIEM MOŻLIWYCH ROZWIĄZAŃ W TYM ZAKRESIE}

Koszty administracyjne funkcjonowania rozszerzonego systemu w przypadku włączenia transportu, rolnictwa i/lub użytkowania budynków do EU ETS zależałyby od zastosowanego podejścia. Wdrożenie podejścia downstream w przypadku wszystkich analizowanych sektorów wiązałoby się z nałożeniem na ogromną liczbę podmiotów obowiązków wynikających z uczestnictwa w systemie. Już samo porównanie liczby instalacji i operatorów statków powietrznych objętych EU ETS z liczbą pojazdów odzwierciedla skalę wyzwania, jakie stanowiłoby włączenie transportu do EU ETS w podejściu downstream. Obecnie EU ETS obejmuje ok. 12 tys. instalacji stacjonarnych i 1,3 tys. operatorów statków powietrznych ${ }^{20}$. W 2014 r. w samej Polsce było ponad 23,5 mln pojazdów (nie licząc przyczep i motocykli), a w Unii Europejskiej było ich ponad $289 \mathrm{mln}^{21}$. Oznacza to, że zastosowanie podejścia downstream charakteryzowałoby się niewspółmiernie wysokimi (w stosunku do efektów - obecnie EU ETS pokrywa 45\% emisji w UE, włączenie transportu oznaczałoby dodatkowe 19 punktów procentowych - por. wyżej) kosztami administracyjnymi działania systemu (z uwagi na wielką liczbę podmiotów) i niepewnościa (monitorowanie, raportowanie i weryfikacja emisji z bardzo rozproszonych „instalacji”). Podobną sytuację obserwuje się w odniesieniu do rolnictwa i użytkowania budynków. W 2013 r. w Polsce było ponad 1,4 mln gospodarstw rolnych, a w całej UE - prawie $11 \mathrm{mln}^{22}$. Z kolei z rezultatów spisu powszechnego dokonanego w Polsce w 2011 r. wynika, że w samej Polsce było ponad 6,1 mln budynków (97,7\% stanowiły budynki mieszkalne) ${ }^{23}$. Reasumując, włączenie transportu, rolnictwa i użytkowania budynków do EU ETS na drodze podejścia downstream byłoby równoznaczne z nałożeniem obowiązków

${ }^{20}$ European Environment Agency, 2016, http://www.eea.europa.eu/data-and-maps/data/data-viewers/emissions-trading-viewer [dostęp: 22.04.2016].

21 Eurostat, http://ec.europa.eu/eurostat/data/database [dostęp: 22.04.2016]. Dla Estonii, Francji i Portugalii wykorzystano do sumowania dane za 2013 r. Należy mieć na uwadze, że prawdopodobnie liczba faktycznie eksploatowanych pojazdów jest znacznie mniejsza. Zdarza się, że właściciele nie wyrejestrowuja pojazdów, które nie są już używane (Ile aut jeździ po polskich drogach?, http://www.motofakty.pl/artykul/ile-aut-jezdzi-po-polskich-drogach.html [dostęp: 28.05.2016]).

${ }^{22}$ Eurostat, http://ec.europa.eu/eurostat/data/database [dostęp: 22.04.2016].

${ }^{23}$ Główny Urząd Statystyczny, Wyniki Narodowego Spisu Powszechnego Ludności i Mieszkań 2011. Podstawowe informacje o sytuacji demograficzno-społecznej ludności Polski oraz zasobach mieszkaniowych, GUS, Warszawa 2012, s. 27. 
wynikających $\mathrm{z}$ uczestnictwa w systemie na bardzo dużą liczbę podmiotów i generowałoby wysokie koszty administracyjne.

Zastosowanie podejścia upstream byłoby zdecydowanie efektywniejsze kosztowo niż rozwiązanie downstream (dla transportu również midstream). Takie rozwiązanie dotyczyłoby stosunkowo nielicznej grupy podmiotów profesjonalnych, którym łatwiej byłoby wdrożyć procedury pomiaru i raportowania emisji. Dodatkowo część z nich (np. rafinerie - dot. transportu, zakłady produkujące amoniak i kwas azotowy, będące półproduktami w wytwarzaniu nawozów azotowych - dot. rolnictwa) ma już pewne doświadczenie w tym zakresie w związku z rozliczaniem emisji pochodzacych z procesu produkcyjnego (podlegają pod EU ETS). Niemniej w przypadku rolnictwa i użytkowania budynków mogłyby pojawić się wątpliwości dotyczące zdefiniowania grupy podmiotów, które powinny być objęte systemem (z uwagi na zróżnicowanie źródeł energii wykorzystywanej w budynkach i produktów zużywanych w rolnictwie).

Podejście downstream jest najbardziej wartościowe z punktu widzenia drugiego kryterium - stymulowania rozwoju świadomości podmiotów bezpośrednio generujących e misje. Jego wdrożenie tworzy bezpośrednie zachęty do redukcji emisji. Redukcje te mogą być osiagane nie tylko na drodze ponoszenia nakładów na rozwiązania niskoemisyjne (por. niżej), ale także na drodze zmiany przyzwyczajeń, np. w przypadku transportu alternatywa bądź uzupełnieniem dla wyboru efektywniejszych silników jest zmiana nawyków komunikacyjnych, tj. podróżowanie samochodem w kilka osób, wykorzystanie środków transportu publicznego, w szczególności szynowego.

$\mathrm{W}$ rozwiązaniach upstream (i midstream dla transportu) cena pozwoleń zostałaby „ukryta” w cenie paliwa lub pojazdu/ nawozów, pasz, środków ochrony roślin/ nośników energii. Wówczas siła przełożenia na jakiekolwiek działania skutkujące zmniejszeniem emisji zależałaby w dużej mierze od ceny pozwoleń na emisję (niska cena pozwoleń spowodowałaby jedynie niewielki wzrost cen paliwa lub samochodów/ produktów wykorzystywanych w rolnictwie/ nośników energii, a zatem mogłaby się nie przełożyć na zmianę postaw emitentów).

Kolejnym kryterium oceny zasadności włączenia analizowanych sektorów do EU ETS jest specyfika kosztów redukcji emisji w tych sektorach. Analizę kosztów redukcji emisji w podziale sektorowym ${ }^{24}$ przeprowadziła m.in. globalna firma konsultingowa McKinsey. W badaniach prowadzonych zarówno w ujęciu globalnym ${ }^{25}$, jak też specyficznie dla Polski ${ }^{26}$,

${ }^{24}$ Szacowanie kosztów redukcji emisji gazów cieplarnianych w przekroju sektorowym wymaga zastosowania wielu założeń odnośnie do scenariusza BAU (ang. business as usual) oraz wielkości kosztów technologii redukcji, co sprawia, że szacunki są obarczone dużym błędem pomiaru. F. Kesicki, Marginal abatement cost curves for policy making - expert-based vs. model-derived curves, paper presented at the 33rd IAEE International Conference, 6-9 June 2010, Rio de Janeiro, Brazil, updated in November 2011, s. 3-4.

${ }^{25}$ T. Nauclér, P. Enkvist, Pathways to a Low-Carbon Economy. Version 2 of the Global Greenhouse Gas Abatement Cost Curve, McKinsey \& Company, 2009; P. Enkvist, J. Dinkel, Ch. Lin, Impact of the Financial Crisis on Carbon Economics. Version 2.1 of the Global Greenhouse Gas Abatement Cost Curve, McKinsey \& Company, 2010.

${ }^{26}$ J. Poświata, W. Bogdan, Ocena potencjału redukcji emisji gazów cieplarnianych w Polsce do roku 2030, McKinsey \& Company, 2009. 
analitycy McKinsey skupili się przede wszystkim na średnim koszcie (społecznym, nie prywatnym) redukcji jednej $1 \mathrm{t} \mathrm{CO}_{2}$, rozumianym jako dodatkowy koszt zastapienia technologią niskoemisyjną technologii ze scenariusza BAU (ang. business as usual) po skorygowaniu o ewentualne oszczędności np. z tytułu mniejszego zużycia energii. Transport i użytkowanie budynków maja w tym kontekście szczególny charakter. Po pierwsze kierunki rozwoju tych sektorów są silnie zależne od decyzji konsumentów. Po drugie, zgodnie z założeniami przyjętymi przez McKinsey, redukcje w tych sektorach charakteryzują się stosunkowo wysokimi nakładami kapitałowymi, ale po uwzględnieniu oszczędności z tytułu mniejszego zużycia energii, koszty redukcji w tych sektorach zamieniaja się w korzyść netto (wniosek ten dotyczy następujacych przedsięwzięć: wzrostu efektywności silników samochodowych oraz termomodernizacji istniejących budynków i podwyższenia wydajności nowych budynków) ${ }^{27}$. Jak jednak wskazują autorzy raportu, na przeszkodzie redukcji $\mathrm{w}$ tych sektorach stoja jednak inne przeszkody - o charakterze strukturalnym. Przykładem takiego problemu jest rozbieżność interesów w przypadku decyzji o charakterystyce energetycznej budynku - decyduje o niej deweloper, a ewentualne korzyści z tytułu oszczędności energii czerpałby przyszły użytkownik. Należy mieć tu na uwadze, że obserwowalna jest tendencja jednostek do stosowania wysokiej stopy dyskontowej przyszłych oszczędności z tytułu mniejszego zużycia energiii ${ }^{28}$ i paliwa ${ }^{29}$. Oznacza to, że użytkownicy budynków oczekuja bardzo szybkiego zwrotu z tytułu oszczędności uzyskanych na drodze termomodernizacji istniejących budynków lub poniesienia dodatkowych nakładów na zmniejszenie zapotrzebowania na energię budynków nowo powstających. Podobnie zachowują się użytkownicy samochodów, kiedy podejmują decyzję o zakupie samochodu z efektywniejszym silnikiem. Ponadto wiele innych czynników ma wpływ na decyzje o zakupie samochodu, szczególnie osobowych (w tym czynniki psychologiczne). Do tego dochodzą obawy konsumentów związane z zaciaganiem zobowiązań w celu sfinansowania działań, skutkujących mniejszymi emisjami. Specyfika kosztów redukcji emisji i jej finansowanie stanowią podstawowy problem redukcji z tych sektorów.

Tymczasem w perspektywie do 2050 r. Unia Europejska ma obniżyć emisje o 80-95\% w stosunku do poziomu z 1990 r. ${ }^{30}$ Tak duża redukcja będzie wymagała obniżenia emisji we wszystkich sektorach, w tym w transporcie i z tytułu użytkowania budynków ${ }^{31}$. Biorąc powyższe pod uwagę, rozwój niskoemisyjnego transportu oraz budownictwa stanowi szczególne wyzwanie dla Unii Europejskiej.

${ }^{27}$ Por. T. Nauclér, P. Enkvist, op. cit., s. 17; P. Enkvist, J. Dinkel, Ch. Lin, op. cit., s. 8; J. Poświata, W. Bogdan, op. cit., s. 7.

${ }^{28}$ T. Nauclér, P. Enkvist, op. cit., s. 41.

${ }^{29}$ International Energy Agency, Improving the Fuel Economy of Road Vehicles. A Policy Package, 2012, http://www.iea.org/publications/pp5_fuel_economy_final.pdf, s. 14-15 [dostęp: 29.04.2016].

${ }^{30}$ Komunikat Komisji do Parlamentu Europejskiego, Rady, Europejskiego Komitetu Ekonomiczno-Społecznego i Komitetu Regionów: Plan działań prowadzący do przejścia na konkurencyjną gospodarkę niskoemisyjną do 2050 r., Bruksela, 8 marca 2011 r., KOM (2011), 112 wersja ostateczna, s. 3.

${ }^{31}$ Ibidem, s. 6, 8-9. 
Komisja Europejska upatruje w użytkowaniu budynków bardzo dużego potencjału redukcyjnego ${ }^{32}$. Z kolei w odniesieniu do transportu wyraża przekonanie, że osiagnięcie przyszłych celów, z uwagi na jego udział w emisjach i specyfikę, wymaga podjęcia działań w tym kierunku i ponoszenia nakładów już teraz ${ }^{33}$. W kontekście powyższych rozważań powstają wątpliwości, czy miałoby to miejsce w przypadku włączenia tego sektora do EU ETS - modelowo redukcje dokonywane są tam, gdzie jest to najtańsze, ale sprawcy emisji z transportu i z tytułu użytkowania budynków nie kierują się wyłącznie rachunkiem ekonomicznym.

Dla rolnictwa koszty redukcji emisji zasadniczo różnią się w zależności od analizowanej praktyki, niemniej w większości przypadków realizacja działań mających na celu ograniczenie emisji gazów cieplarnianych nie cechuje się wysokimi nakładami ${ }^{34}$.

Przeciwko włączeniu wszystkich analizowanych sektorów do EU ETS przemawia także sposób, w jaki szacowane są ich emisje. Należy mieć na uwadze, że każda 1 t $\mathrm{CO}_{2}$ emisji podmiotów objętych EU ETS jest przedmiotem rozliczenia, zatem zasadne jest, by emisje objęte EU ETS były w miarę możliwości precyzyjnie mierzalne (co ma miejsce w przypadku instalacji przemysłowych). Emisje mierzone sa na poziomie instalacji lub operatora statków powietrznych, a sposoby monitorowania emisji są szczegółowo uregulowane ${ }^{35}$. Takie rozwiazanie gwarantuje rzeczywiste redukcje emisji i sprawiedliwy podział obciążeń w ramach systemu. Tymczasem emisje z transportu, rolnictwa i użytkowania budynków są obecnie szacowane jedynie w sposób zagregowany, dla całych sektorów, na potrzeby UNFCCC. Brakuje zatem na chwilę obecną odpowiednich procedur ich monitorowania na poziomie pojedynczego podmiotu. Należy mieć również na uwadze, że obliczenia dotyczące emisji metanu i podtlenku azotu (gazy te sa głównymi gazami cieplarnianymi pochodzącymi z sektora rolnictwa) są obarczone stosunkowo dużą niepewnością oszacowań emisji ${ }^{36}$. Utrudnia to ich monitorowanie i weryfikację bez względu na podmiot objęty obowiązkiem ich rozliczania. W opinii autorki podważa to zasadność włączenia tego sektora do EU ETS.

W kontekście precyzyjności szacowania emisji szczególne wady prezentuje także zastosowanie podejścia midstream $\mathrm{w}$ transporcie. W tym wariancie obowiązkiem monitorowania i rozliczania emisji zostałaby objęta niewielka grupa podmiotów, ale pojawiłyby się problemy związane z niepewnością co do poprawności szacunków (np. zaniżanie emisji na etapie testów u producenta) i rozliczaniem emisji w czasie (okres użytkowania pojazdów jest

32 Ibidem, s. 5-6.

${ }^{33}$ Biała Księga: Plan utworzenia jednolitego europejskiego obszaru transportu - dążenie do osiagnięcia konkurencyjnego i zasobooszczędnego systemu transportu, Bruksela, 28 marca 2011 r., KOM (2011), 144 wersja ostateczna, s. 6.

${ }^{34}$ Por. T. Nauclér, P. Enkvist, op. cit., s. 17; P. Enkvist, J. Dinkel, Ch. Lin, op. cit., s. 8; J. Poświata, W. Bogdan, op. cit., s. 7.

${ }^{35}$ Rozporządzenie Komisji (UE) nr 601/2012 z 21 czerwca 2012 r. w sprawie monitorowania i raportowania w zakresie emisji gazów cieplarnianych zgodnie z dyrektywą 2003/87/WE Parlamentu Europejskiego i Rady, Dz. Urz. L 181 z 12 lipca 2012 r., s. 30.

${ }^{36}$ Por. A. Olecka et al., op. cit., s. 351-359. 
zazwyczaj dłuższy niż czas trwania okresu rozliczeniowego w ramach EU ETS) oraz mogłyby zaistnieć duże rozbieżności pomiędzy wartościami rzeczywistymi i szacunkowymi, wynikające z dłuższego lub intensywniejszego niż pierwotnie zakładano użytkowania pojazdów (zastosowanie podejścia midstream jest równoznaczne z rozliczaniem emisji potencjalnych, a nie rzeczywistych).

Dużym ryzykiem przeszacowania/niedoszacowania rzeczywistych emisji cechuje się też zastosowanie podejścia upstream we włączeniu rolnictwa i użytkowania budynków do systemu handlu emisjami. Podyktowane jest to chociażby zróżnicowaniem źródeł stosowanych w rolnictwie produktów (nawozy, środki ochrony roślin, pasze itd.) oraz wykorzystywanych źródeł energii dla budynków (energia elektryczna, gaz, węgiel, olej opałowy, drewno opałowe itd.).

Warto tu również wspomnieć, że raporty z emisji gazów cieplarnianych podmiotów objętych EU ETS, będące podstawą rozliczenia wielkości emisji, podlegaja procesowi weryfikacji, co niejako ogólnie wyklucza zastosowanie podejścia downstream, gdyby nowe podmioty również miały podlegać wszystkim aktualnym obowiązkom wynikającym z przynależności do systemu. Tabela 3 zawiera podsumowanie powyższych rozważań.

Tabela 3

Ocena poszczególnych rozwiązań w zakresie włączenia transportu, rolnictwa i użytkowania budynków do EU ETS

\begin{tabular}{|c|c|c|c|}
\hline Sektor & Podejście & $\begin{array}{l}\text { Mocne strony } \\
\text { rozwiązania }^{a}\end{array}$ & Słabe strony rozwiązania \\
\hline \multirow{3}{*}{ 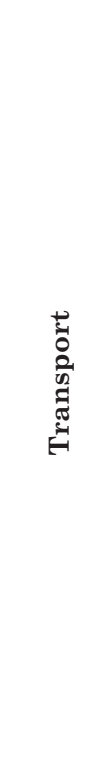 } & Upstream & $\begin{array}{l}\text { - niskie koszty ad- } \\
\text { ministracyjne }^{b}\end{array}$ & $\begin{array}{l}\text { - słabe oddziaływanie na świadomość emi- } \\
\text { tentów } \\
\text { - możliwość niedostatecznego stymulowa- } \\
\text { nia inwestycji w technologie niskoemisyj- } \\
\text { ne z punktu widzenia długoterminowych } \\
\text { celów redukcyjnych }\end{array}$ \\
\hline & Midstream & $\begin{array}{l}\text { - niskie koszty ad- } \\
\text { ministracyjne }^{b}\end{array}$ & $\begin{array}{l}\text { - słabe oddziaływanie na świadomość emi- } \\
\text { tentów } \\
\text { - możliwość niedostatecznego stymulowa- } \\
\text { nia inwestycji w technologie niskoemisyj- } \\
\text { ne z punktu widzenia długoterminowych } \\
\text { celów redukcyjnych } \\
\text { - mierzenie emisji potencjalnych, a nie } \\
\text { rzeczywistych }\end{array}$ \\
\hline & Downstream & $\begin{array}{l}\text { - silne oddzia- } \\
\text { ływanie na } \\
\text { świadomość emi- } \\
\text { tentów }\end{array}$ & $\begin{array}{l}\text { - wysokie koszty administracyjne } \\
\text { - możliwość niedostatecznego stymulowa- } \\
\text { nia inwestycji w technologie niskoemisyj- } \\
\text { ne z punktu widzenia długoterminowych } \\
\text { celów redukcyjnych } \\
\text { - problemy techniczne szacowania i wery- } \\
\text { fikacji emisji }\end{array}$ \\
\hline
\end{tabular}




\begin{tabular}{|c|c|c|c|}
\hline \multirow{2}{*}{$\underset{\substack{0 \\
\vdots \\
0 \\
0 \\
0 \\
0}}{0}$} & Upstream & $\begin{array}{l}\text { - niskie koszty ad- } \\
\text { ministracyjne }^{b}\end{array}$ & $\begin{array}{l}\text { - słabe oddziaływanie na świadomość emi- } \\
\text { tentów } \\
\text { - relatywnie duża niepewność oszacowań } \\
\text { emisji już na poziomie całego sektora }\end{array}$ \\
\hline & Downstream & $\begin{array}{l}\text { - silne oddzia- } \\
\text { ływanie na } \\
\text { świadomość emi- } \\
\text { tentów }\end{array}$ & $\begin{array}{l}\text { - wysokie koszty administracyjne } \\
\text { - relatywnie duża niepewność oszacowań } \\
\text { emisji już na poziomie całego sektora }\end{array}$ \\
\hline \multirow{2}{*}{ 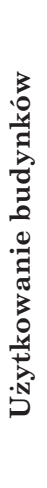 } & Upstream & $\begin{array}{l}\text { - niskie koszty ad- } \\
\text { ministracyjne }^{b}\end{array}$ & $\begin{array}{l}\text { - słabe oddziaływanie na świadomość emi- } \\
\text { tentów } \\
\text { - możliwość niedostatecznego stymulowa- } \\
\text { nia inwestycji w technologie niskoemisyj- } \\
\text { ne z punktu widzenia długoterminowych } \\
\text { celów redukcyjnych } \\
\text { - problemy techniczne szacowania emisji }\end{array}$ \\
\hline & Downstream & $\begin{array}{l}\text { - silne oddzia- } \\
\text { ływanie na } \\
\text { świadomość emi- } \\
\text { tentów }\end{array}$ & $\begin{array}{l}\text { - wysokie koszty administracyjne } \\
\text { - możliwość niedostatecznego stymulowa- } \\
\text { nia inwestycji w technologie niskoemisyj- } \\
\text { ne z punktu widzenia długoterminowych } \\
\text { celów redukcyjnych } \\
\text { - problemy techniczne szacowania i wery- } \\
\text { fikacji emisji }\end{array}$ \\
\hline
\end{tabular}

${ }^{a}$ Ogólne zalety wykorzystania handlu emisjami jako narzędzia redukcji emisji zostały opisane wcześniej i mają tu zastosowanie.

${ }^{b} \mathrm{~W}$ porównaniu z innymi analizowanymi w opracowaniu rozwiązaniami.

Źródło: opracowanie własne.

\section{PODSUMOWANIE}

Konkludując, włączenie sektorów obecnie nieobjętych EU ETS do systemu nie byłoby działaniem ani łatwym, ani niebudzacym wątpliwości dotyczących skuteczności takiego postępowania. Europejski System Handlu Emisjami jest specyficznym systemem, wymagającym od podmiotów nim objętych dokładnego monitorowania i rozliczania emisji. Przeprowadzona analiza wykazała, że wdrożenie któregokolwiek podejścia (upstream, midstream, downstream) w odniesieniu do transportu, rolnictwa i użytkowania budynków nie jest pozbawione wad i każde rozwiązanie jest obarczone niepewnością co do jego skuteczności.

Powyższa ocena nie oznacza, że na tej podstawie można wysnuć wniosek, że włączenie analizowanych sektorów do EU ETS jest złym sposobem na osiagnięcie w nich redukcji emisji bądź że jest rozwiązaniem gorszym od innych (czyli przede wszystkim zastosowania instrumentów bezpośrednich, ale też np. systemów handlu emisjami skierowanych do poszczególnych sektorów). Wydawanie tego typu osądów wymaga znacznie szerszych i głębszych badań. Nie ma wątpliwości, że z uwagi na wagę środowiskową i ekonomiczna problemu tego typu badania powinny być realizowane, a ich wyniki brane pod uwagę przy podejmowaniu decyzji politycznych. 


\title{
CONTRIBUTION TO THE DISCUSSION ON THE RATIONALE OF THE INCLUSION OF NON-ETS SECTORS INTO THE EU ETS
}

\author{
Sum mary
}

The paper contributes to the discussion on the possibilities of reducing greenhouse gases emissions from the sectors that are not covered by the European Union Emissions Trading System (the so called non-ETS sectors). The author deals with some issues that should be taken into consideration while evaluating the validity of bringing additional sectors (i.e. transport, agriculture and buildings) into the European Union Emissions Trading System. Different approaches to including new sectors to the Emissions Trading System are considered. The research methods include descriptive and comparative analysis. 
